\title{
Improving Students' Activeness and Learning Outcomes in Discussions on Low Plants Taxonomy through Listening Teams Learning Model
}

\author{
Nevrita \\ Biology Education Study Program \\ FKIP Universitas Maritim Raja Ali Haji \\ nevrita69@gmail.com
}

\begin{abstract}
This research was conducted to see whether the listening team learning model in discussions on Low Plant Taxonomy course can enhance the students' activeness and their learning outcomes. The research was conducted at Biology Education Study Program, in the 3rd-semester's student at academic year 2016/2017 which was taking Low Plant Taxonomy course were the subject of the research. This research was classified as a classroom action research, which was conducted through four stages in each cycle, i.e. planning, implementation, observation, and reflection. Test and non-test were used as the data collecting techniques. The tests were used to gather the students' learning outcomes on Low Plant Taxonomy course. Non-tests were done through questionnaires and observation sheets. The results showed that Listening Team Learning Model can enhance the students' activeness during the discussions. The average score of students' activeness during the lectures in first and second cycles was increased. The average score in the first cycle was 70.78, and in the second cycle was 78.90. Likewise, students' results in first and second cycles were also significantly increased. The average score of students' learning outcomes in the first cycle was 64.89 and in the second cycle was $\mathbf{7 3 . 8 4}$.
\end{abstract}

Keywords-component; listening teams; classroom action research; activeness; learning outcome

\section{INTRODUCTION}

Learning system in a college or university is frequently dominated by speech and presentation of material by lecturers without engaging students' participation. However, with the evolution of education, learning models started to reform and be abandoned by the lecturer. Since then, learning activities started to engage students as learning objects. One form of learning activities that engage students are group works where students are assigned with writing papers that shall be presented before the class. One of the widely-used learning methods is a discussion, in which the lecturer acts as a learning facilitator and summarizes all the learning materials as well as unbends the misguided materials or misleading scientific concepts. The expected result from the aforementioned learning method is that the students become more active during lectures. Nonetheless, the fact shows that the discussion method fails to encourage students to be fully active during lectures; except that only a small number of students demonstrate better competence and more active participation, while the rest of the students are dominantly good listeners. Lecturers should be aware of choosing proper method and model of lectures which involve every single student and promote students to be more active during the lectures. The course of Lower Plants Taxonomy is the course that potentially causes boredom and dullness to students when presented with lecture method and thereby it leads to an uninteresting class to follow. Hence, a good lecturer should be someone who would always try his best and opts for appropriate teaching methods and models in delivering the content of the learning materials. Due to the limitation of laboratory equipment, an experiment cannot be optimally conducted. Therefore, the discussion is the best option to present the material of the course. In order for the learning objectives of this course to be achieved, then the discussion is considered to be the proper method. Similarly, to promote students' active participation in discussion, the selection of the right model as a supplementary to this activity of discussion poses the right choice. A number of learning models might serve as the best option in the discussion of the course, one of which is the model of "Listening Team".

The term 'Listening Teams' originates from two single words: 'listening' and 'team'. 'Listening' means to hear or to listen, and 'team' means a group of people. By identifying the literal definitions of both terms, the phrase 'listening team' can be defined as a group activity for listening to or paying attention to the material. Listening Teams is a learning strategy that helps students keep concentrated and focused in lessons in which students are divided into groups assigned to certain tasks or responsibilities related to the material [1]. The Listening Teams Learning Model is aimed at allowing students to divide themselves into groups and be given different tasks to each group so that students are able to work together with their peers in solving a problem so as to avoid boredom in the classroom. The purpose of applying the Listening Teams Learning Model is to practice students to become familiar with harmonious group study and to achieve more effective learning outcomes [2]. The use of Listening Teams optimizes students' sense of hearing (in addition to other senses) and is expected to help learners to stay focused and alert during lessons taking place [3]. It is inferred that based on the above explanation, the Listening Teams is a learning model that optimizes students' auditory sense and divides students into groups with specific tasks so that students remain focused, concentrated, active, not bored and able to work harmoniously together to solve any problems encountered. Some steps in the Listening Teams Learning 
Model are as follows: First, the students are divided into 4 teams and the teams are assigned with tasks; team $\mathrm{A}$ as a questioner, team B as a supporter, team $\mathrm{C}$ as an opponent and team $\mathrm{D}$ as a conclusion drawer. Second, a presenter reports on the results of his research, once completed, each group is allocated time to complete the task in accordance with their respective roles [4].

Students' activeness involves student activities during the learning process in which their physical aspect and spiritual aspect are activated and hence must be understood and developed by teachers in order to achieve learning objectives which are marked by the involvement of intellectual, emotional, and physical aspects. The students' active participation in learning affects their achieved learning outcomes [5]. Another definition of students' activeness in learning is one of teaching and learning strategies that require students' activeness and participation at a maximum in the subject being discussed so that students are able to change their behaviors or any activities/events more effectively and efficiently [6]. From the above definition, activeness is delineated as an activity during a learning process in which students are advocated to be active as optimal as possible and be able to change their behaviors which eventually affects their learning outcomes.

Learning is a process to make changes within students' selves by interacting with the environment with the purpose of gaining cognitive, affective and psychomotor changes. According to 1) learning is a behavior changing process, where those changes could lead to better behavior or could lead to the possibility of worse behavior; 2) learning is changing which occur through training or experience; which means that the changes caused by growth or maturity are not considered as a learning outcome; such as changes which occur in a baby; 3) learning is defined as steady changes which are a final result of a long period of time process. This long period of time process has no exact duration, but those changes should be the end of a long period of time which may last for days, months or even years; 4) changes in behavior due to learning process are related to various aspects of personality, both physically and psychologically, including changes in problem/thinking solving, skills, competencies, habits, or attitudes [7]. Such changes can be referred as the result of learning process Learning outcomes are often used as a parameter to find out how far one has acquired the material that has been taught [8]. According to Gagne, the results of performance outcomes which can be observed in an individual is referred to as capability, among others are intellectual skills, cognitive strategies, verbal information, motor skills and attitudes [9]. Learning outcomes are students' achievement after participating in the learning process. Students' learning outcomes obtained from an activity as a result of changes in behavior is represented by scores/values obtained from the test results of learning upon completing the learning process. Conducting an evaluation and an assessment of learning outcomes is of great importance since learning outcomes are an expression and manifestation of the results of learning process [7]. Based on the aforementioned notions, it can be summed up that learning outcomes are a measure to determine students' acquisition towards specific course as represented by scores/values during the learning process.
Based on preliminary survey results conducted on students, the model listening team turned out to be unfamiliar to them and it has not been used during lectures. In an attempt to promote students' active participation and learning outcomes, the researcher feels it is imperative to conduct a research entitled "Improving Students' Active Participation and Learning Outcomes during Discussions of Lower Plants Taxonomy through Listening Teams Learning Model at Biology Education Study Program - Faculty of Teacher Training and Education, University of Maritim Raja Ali Haji”.

\section{METHOD}

This research was a classroom action research (CAR). CAR can be defined as the process of observing learning problems in a classroom through self-reflection in an attempt to solve the problem by doing various planned actions in real situations as well as to analyze any effect emanated during the process [10]. Another rationale argues that CAR is an investigation of learning activities in the form of an action that is purposely raised and occurs in a classroom at the same time [11]. Based on these points of view, it can be concluded that a class action research is an assessment and investigation of the learning process that takes place in a classroom through selfreflection in solving problems with various actions. The research was conducted on students of Biology Education Study Program, at the Faculty of Teacher Training and Education, University of Maritim Raja Ali Haji (UMRAH) in the course of Lower Plants Taxonomy in the academic years of $2016 / 2017$.

A class action research was performed in several cycles and each cycle was comprised of four phases: planning, implementation, observation, and reflection. In case all four phases have been carried out in the first cycle and the achievement of learning outcomes turns not to be as expected, we can then proceed to the next cycle and so on until the researcher is assured and the achievement of learning outcomes are in accordance with the expectations. The data were collected by implementing a test and a non-test. The nontest was conducted by administering questionnaires and observation sheets, while the test was used to observe the achieved students' learning outcomes.

\section{RESULTS AND DISCUSSION}

The research was carried out until the second cycle. The first cycle was comprised of 8 sessions and the second cycle was comprised of 6 sessions. At the end of the first cycle on the reflection result, the progress of learning during the first cycle will be uncovered. From the reflection results, some weaknesses would be discovered. In the second cycle of planning and implementation phase, these weaknesses are improved and provided with increased treatment. Thereby, changes will occur during the implementation in the first cycle and the second cycle.

\section{A. The Results of the First Cycle}

Below are the results and discussion of the first cycle.

1) Planning 
The researcher drafted a Lesson Plan and prepared necessary instruments in the forms of tests and observation.

\section{2) Implementation}

The implementation phase of the first cycle is conducted in 7 sessions. The first session to the seventh session are the phases of implementing an activity of Listening Teams Learning Model, the eighth session is performing a test to a total of 26 students. On the first session, the researcher explains to students about a course contract, distributes course materials for group discussion and divides the students into several groups. Each group consists of four and five students. The second session to the seventh session is the phases of implementing an activity of Listening Teams LearningModel. In the eighth session, formative assessment was conducted.

3) Observation

The observation results of students' active participation during the learning process in which Listening Teams Learning Model is implemented can be represented in Table I. Based on the Table I the percentage of students' active participation can be identified. Students' activeness in responding to questions has a small percentage as compared to other subcategories of active participation. The percentage of asking questions has the greatest percentage of active participation subcategory among others. Upon converting the average values of students' active participation, the value of 70.78 was obtained.

TABLE I. STUDENTS' ACTIVE PARTICIPATION IN THE FIRST CYCLE

\begin{tabular}{|c|c|c|c|}
\hline No. & Active Participation & Percentage & $\begin{array}{c}\text { Average } \\
\text { Value } \\
\text { Conversion }\end{array}$ \\
\hline 1 & Asking Questions & $88.46 \%$ & \multirow{3}{*}{70.78} \\
\hline 2 & Answering Questions & $80.13 \%$ & \\
\hline 3 & $\begin{array}{l}\text { Responding to questions or } \\
\text { answers }\end{array}$ & $65.59 \%$ & \\
\hline
\end{tabular}

The results of students' learning outcomes during the learning process by using the Listening Teams Learning Model implemented, in the first cycle was 64.89. Compared to its target of 66 , this value has not yet reached the target of students learning outcomes for the first cycle.

4) Reflection

Some shortcomings discovered from observation in the first cycle are as follows.

a) Only a small fraction of students in the group are willing to deliver and present their materials. Those who deliver and present the material tend to be represented singly by one student.

b) There are some students who have no courage to ask questions.

c) There are some students who cannot answer questions.

d) Most of the students have no courage to respond to questions and respond to answers.

Based on the reflection results in the first cycle, it is then necessary to proceed to the second cycle.

\section{B. The Results of the Second Cycle}

Below are the results and discussion of the second cycle.

1) Planning

Researcher drafted a Lesson Plan and prepared necessary instruments in the forms of tests and observation. In this second cycle, an activity action is planned in accordance with the reflection results of the first cycle.

a) All members of the group were given the responsibility for the material to be presented.

b) All members of the group were prompted to have courage in asking and answering questions.

c) All members of the group were given the opportunity to respond to questions and answers raised by other students.

\section{2) Implementation}

The implementation phase of the second cycle is conducted in five sessions. The ninth session to the thirteenth session are the phases of implementing an activity of Listening Teams Learning Model, the fourteenth session is performing a test to a total of 26 students.

3) Observation

The observation results of students' active participation during the learning process in which Listening Teams Learning Model is implemented can be represented in the following Table II.

TABLE II. STUDENTS' ACTIVE PARTICIPATION IN THE SECOND CYCLE

\begin{tabular}{|c|l|c|c|}
\hline No. & \multicolumn{1}{|c|}{ Active Participation } & Percentage & $\begin{array}{c}\text { Average } \\
\text { Value } \\
\text { Conversion }\end{array}$ \\
\hline 1 & Asking Questions & $90.77 \%$ & \multirow{2}{*}{78.90} \\
\hline 2 & Answering Questions & $88.46 \%$ & \\
\cline { 1 - 2 } 3 & $\begin{array}{l}\text { Responding to questions or } \\
\text { answers }\end{array}$ & $83.08 \%$ & \\
\hline
\end{tabular}

Based on the above table, the percentage of students' active participation has increased significantly. Active participation in asking questions is still the highest percentage as compared to another sub-category of active participation. Responding to questions and answers has the smallest percentage among other sub-categories. Nonetheless, its learning outcome percentage shows an increase as compared to the first cycle. When these classifications are converted to a score, an average value of students' active participation of 78.90 was obtained.

The outcome of listening teams learning model in the second cycle was 73,84 . It was exceeded the target value of 66 . Hence, the student learning results in the second cycle have reached the target.

4) Reflection

Some shortcomings discovered from observation in the first cycle are as follows.

a) All students in the groups presented their materials. 
b) Most of the students had the courage to ask questions.

c) There are some students who cannot answer questions despite the percentage has been reduced.

d) The percentage of students' responding to questions and answers has shown an increase.

\section{Discussion of Active Participation in the First and the Second Cycles}

Based on the research results of the first cycle and of the second cycle, students' active participation during the implementation of Listening Teams Learning Model can be represented as Table III below. The students' active participation in the form of scores or grades can be represented in Table IV.

Table III above indicates that students' active participation in the first cycle and in the second cycle had an increase. The average percentage in the first cycle was $79.06 \%$ and the average percentage in the second cycle was $87.44 \%$. The percentage of increase in the first cycle and in the second cycle is $8.38 \%$. Meanwhile, students' active participation when converted into value as illustrated in table 4 had an increase in which the deviation in the increase amounted to 8.12. Based on the above-mentioned score, it can be concluded that the Listening Teams Learning Model can enhance students' active participation.

TABLE III. STUDENTS' ACTIVE PARTICIPATION

\begin{tabular}{|c|l|c|c|}
\hline No. & Active Participation & Cycle I (\%) & Cycle II (\%) \\
\hline 1 & Asking questions & $88.46 \%$ & $90.77 \%$ \\
\hline 2 & Answering questions & $80.13 \%$ & $88.46 \%$ \\
\hline 3 & $\begin{array}{l}\text { Responding to } \\
\text { questions or answers }\end{array}$ & $65.59 \%$ & $83.08 \%$ \\
\hline & Average Value & $79.06 \%$ & $87.44 \%$ \\
\hline
\end{tabular}

TABLE IV. CONVERSION RESULTS OF STUDENTS' ACTIVE PARTICIPATION

\begin{tabular}{|c|c|c|c|}
\hline Cycle & $\begin{array}{c}\text { Average Active } \\
\text { Participation }\end{array}$ & Target & Score Deviation \\
\hline I & 70.78 & 66 & \multirow{2}{*}{8.12} \\
\hline II & 78.90 & 66 & \\
\hline
\end{tabular}

A. Discussion of Learning Outcome in the First Cycle and in the Second Cycle

Students' learning outcome during learning process where the Listening Teams Learning Model is implemented can be seen in Table V.

TABLE V. STUDENTS' LEARNING OUTCOMES IN THE FIRST AND IN THE SECOND CYCLES

\begin{tabular}{|c|c|c|c|}
\hline Cycle & $\begin{array}{c}\text { Average of Learning } \\
\text { Outcome }\end{array}$ & Target & Score Deviation \\
\hline I & 64.89 & 66 & \multirow{2}{*}{9.05} \\
\hline II & 73.84 & 66 & \\
\hline
\end{tabular}

The above table 5 shows that the students' learning outcomes obtained by students in the first cycle are 64.89 . Compared to the target to be achieved, students' learning outcomes in the first cycle has not reached the target. In the second cycle, students' outcome is at 73.84 with a deviation of
9.05 from the first cycle. Based on the above gain, it can be concluded that students' learning outcomes increased due to the implementation of Listening Teams Learning Model.

\section{B. Results of Analysis and Discussion of Questionnaires}

To further strengthen this research, it is imperative to distribute questionnaires to students. Questionnaires were distributed for the purpose of determining how engaging this listening teams model is in the method of discussion and thus makes the discussion model to be no longer boring for students and becomes a more varied method in which listening teams model is integrated. Results of analysis of students' questionnaires can be seen in the following Table VI.

In Table VI, data shows clearly that Listening Teams Learning Model leads students to become more active in discussions. From observations conducted during the research, it is indicated that Listening Teams Learning Model brings about students' active participation in presenting papers, asking questions, answering questions, expressing their opinions, and giving advice. The above data also indicate that the Listening Teams Learning Model triggers students to find information in order to solve problems in the ongoing discussion. It is also inferred that during a discussion where the Listening Team Learning Model is implemented, students make every effort to be able to identify problems in the discussion, and together discuss with other group members to find answers or problems in the discussions.

TABLE VI. STUDENTS' QUESTIONNAIRES ANALYSIS

\begin{tabular}{|c|l|c|c|}
\hline No & \multicolumn{1}{|c|}{ Statements } & Scores & Percentage \\
\hline 1 & $\begin{array}{l}\text { This Listening Teams Learning Model is } \\
\text { one of the interesting methods if } \\
\text { implemented during lectures. }\end{array}$ & 26 & 100 \\
\hline 2 & $\begin{array}{l}\text { This Listening Teams Learning Model } \\
\text { enables me to understand the course } \\
\text { materials. }\end{array}$ & $\begin{array}{l}\text { This Listening Teams Learning Model } \\
\text { encourages me to be more active in class } \\
\text { discussions. }\end{array}$ & $\begin{array}{l}26 \\
\text { This Listening Teams Learning Model } \\
\text { motivates me to find the data/ information } \\
\text { from various sources to solve problems } \\
\text { encountered in the materials. }\end{array}$ \\
\hline 5 & $\begin{array}{l}\text { Listening Teams Learning Model drives } \\
\text { me to be more active in expressing } \\
\text { opinions. }\end{array}$ & 26 & 100 \\
\hline
\end{tabular}

\section{IV.CONCLUSION AND SUGGESTIONS}

The results of this study concluded that Listening Teams Learning Model during discussions in the course of Lower Plants Taxonomy in Biology Education Study Program, Faculty of Teacher Training and Education, University of Maritim Raja Ali Haji can potentially enhance students' active participation and learning outcomes. This can be seen from students' learning outcomes achieved during the learning process. In the first cycle, the average value of students' active participation was 70.78, while in the second cycle was 78.90. The average value of students' learning outcome in the first cycle was 64.89 and in the second cycle, the average value was 73.84 . 
Some suggestions are proposed in the implementation of listening teams model during discussion class in Biology Education Study Program, Faculty of Teacher Training and Education, University of Maritim Raja Ali Haji including:

1) Listening Teams Learning Model is one of the proper models to be implemented in the course of Lower Plants Taxonomy.

2) This Listening Teams Learning Model can also be applied to other courses of studies by integrating it with other learning models.

3) During the learning process in the course, lecturers are expected to be able to use a variety of learning models that trigger students to be more actively engaged and improve students' learning outcomes.

\section{REFERENCES}

[1] H. Zaini, Strategi Pembelajaran Aktif. Yokyakarta: CTSD, 2007.

[2] I. M. Sari, "Penggunaan Model Listening Team sebagai Sarana Meningkatkan Kemampuan Bertanya pada Pembelajaran IPA Siswa Kelas X SMK YP 17-2 MadiunNo Title,” J. Florea, vol. 2, no. 1, pp. 23 28, 2015.

[3] M. Iqbal Lubis, "Pengaruh Model Pembelajaran Kooperatif Listening Team terhadap Pemahaman Siswa di Sekolah Menengah Atas Negeri 1 Kuantan Singingi," J. Penelit. Sos. keagamaan, vol. 17, no. 2, pp. 265280, 2014.

[4] A. Suprijono, Cooperative Learning Teori dan Aplikasi. Surabaya: Blog History Education, 2009.

[5] R. Vitasari, "Peningkatan Keaktifan dan Hasil Belajar Matematika melalui Model Problem Based Learning Siswa Kelas V SD Negeri 5 Kutosari," digilib.uinsby.ac.id, 2013. .

[6] S. Widowati, "Upaya Meningkatkan Keaktifan dan Prestasi Belajar Matematika Siswa dengan Menggunakan Pembelajaran Kooperatif Tipe Two Stay Two Stray (TSTS)," vol. 1, no. 1, pp. 7-21, 2015.

[7] R. Fitri, "Penerapan Strategi The Firing Line pada Pembalajaran Matematika Siswa Kelas XI IPS SMA Negeri 1 Batipuluh," vol. 3, no. 1, pp. 18-22, 2014.

[8] Purwanto, Evaluasi Hasil Belajar. Yokyakarta: Pustaka Pelajar, 2014.

[9] W. Jufri, Belajar dan Pembelajaran Sains. Bandung: Pustaka Reka Cipta, 2013.

[10] W. Sanjaya, Penelitian Tindakan Kelas, 5th ed. Kencana, 2013.

[11] S. Suharsimi Arikunto, Suhardjono, Penelitian Tindakan Kelas, 1st ed. Jakarta: Bumi Aksara, 2006. 